images that track large-scale features over time.

The mission has also not shrugged off all consequences of its long and unexpected cruise around the Sun. One camera malfunctioned in January, probably because of gradual contamination of a helium coolant with water vapour over the years, said Satoh. Engineers have now fixed the problem by warming the coolant to disperse the vapour, but it took a while. "We had a painful blank of about a month," says Satoh.

Planetary scientists outside of JAXA will have to wait a year from acquisition to access the data, but they are nonetheless excited by the probe's initial success. Two Venus-based projects are among five proposals shortlisted by NASA for possible launch in the early 2020 s. The agency is expected to decide by the end of December, and Venus missions could get a boost from Akatsuki's success - especially if the orbiter finds intriguing features that require follow up, says Smrekar, who leads one of the Venus proposals that NASA is considering, the proposed VERITAS radar orbiter. "If they're able to see new volcanism, for example, it definitely makes the case for going back to explore more fully," she says. - SEE EDITORIAL P.148

US rethinks crop regulation

Committee begins study to guide oversight of gene-edited organisms.

\section{BY HEIDI LEDFORD}

$\mathrm{T}$ The industry that has blanketed more than 181 million hectares of the world's farmland with genetically modified (GM) crops is in the middle of a sea change. Improved techniques for altering crop genomes are already bringing a new generation of plant varieties to the market and around the world, regulators are playing catch-up.

"A few brave countries have already made statements," says Piet van der Meer, a biologist and lawyer at Ghent University in Belgium. "But most are struggling with it."

On 18 April, the US National Academies of Sciences, Engineering and Medicine will begin its first meeting of a committee charged with ending the struggle. The committee, which is sponsored by the US Department of Agriculture (USDA) and two other agencies, has been asked to predict what advances will be made in biotechnology products over the next $5-10$ years. It is scheduled to report by the end of the year on the steps that regulators need to take to prepare themselves. The result could inform an ongoing USDA effort to re-assess its

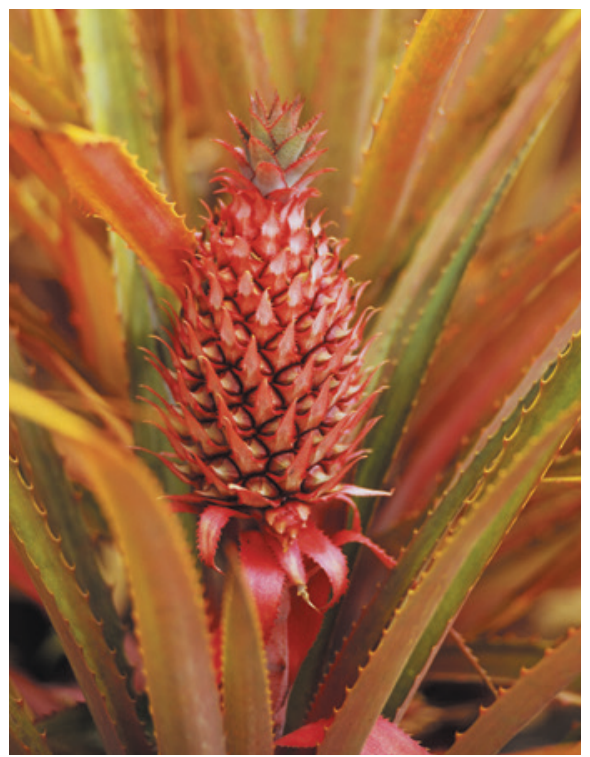

The genetically engineered pink pineapple can be imported into the United States.

process for evaluating engineered crops.

Researchers around the world are watching closely (see 'Global governance'). “Crops travel around the globe," says René Custers, manager of regulatory and responsible research at VIB, a life-sciences research institute in Ghent. "It is important to see what is happening in the rest of the world."

\section{RIPE FOR CHANGE}

Many feel that regulations in the United States, which grows more GM crops than any other country, are particularly ripe for change. The USDA itself has acknowledged that it might be over-regulating some crops if they have traits that have already been scrutinized. Also, it uses its authority to restrict the release of 'plant pests' as a way to regulate GM crops - an approach that applied widely in the 1980 s, when crops were often created using genetic elements from plant viruses or bacteria.

But researchers have since developed tools that do not rely on these components. Over the past five years, the USDA has determined that about 30 types of GM plant - from soya beans whose oil has a longer shelf life, to pineapples with rose-coloured flesh - do not fall under its regulatory rubric. Some were made using gene-editing techniques.

"One of the things that has to happen is to plug

\title{
GLOBAL GOVERNANCE
}

\section{Nations take a variety of approaches to regulating gene-edited products.}

Like the United States, many countries are grappling with how to regulate crops that have been engineered using gene editing and other 'new breeding techniques' (NBTs).

Argentina In 2015, regulators decided that crops made using NBTs would be reviewed on a case-by-case basis.

Australia A 2013 workshop convened by the Food Standards of Australia and New Zealand recommended that NBT crops bearing simple deletions need not be considered GM food, but those with inserted genes should.

European Union The European Commission is expected this year to produce long-delayed advice on applying existing regulations to NBT crops.

Japan No official stance on gene-edited technologies, the products of which do not fall under the country's definition of a 'transgenic' crop.

Canada Decisions are made on the basis of whether the crops have new traits, irrespective of how the traits are produced.

New Zealand The Environmental Protection Authority determined that some crops made through NBTs would not be regulated, but the high court overruled the decision in 2014. H.L. 
that huge hole," says Doug Gurian-Sherman, director of sustainable agriculture at the Center for Food Safety, an environmental-advocacy group in Washington DC. "Whether you think they're over-regulated or under-regulated or just not intelligently regulated, there's nobody who thinks this is appropriate."

And developers eager to market gene-edited varieties want clarity as to how the USDA will view the crops, says Daniel Voytas, chief science officer at Calyxt, a plant biotechnology company in New Brighton, Minnesota. The agency has already determined that it will not regulate several crops that have been developed using two editing tools - zinc-finger nucleases and TALENs - and it is currently considering a non-browning mushroom that was made using another, CRISPR-Cas9.

\section{CASE BY CASE}

These crops embody the simplest application of genome modification: deleting a small section of the genome to disrupt a gene. Calyxt, for example, used TALENs to edit a single gene in the parent plant and generate a variety of wheat with improved resistance to powdery mildew. On 11 February, the USDA informed Calyxt that it would not regulate the crop.

But more-sophisticated edits - such as rewriting genes or inserting new ones - are around the corner, Voytas says. "We don't understand how those crop varieties are going to be regulated," he says. "And they're already in the works."

On 5 February, the USDA released four broad regulatory scenarios that are open to public comment until 21 April. The draft proposed a definition of "products of biotechnology" that encompasses organisms in which segments of the genome have been deleted, added or altered. "Sometimes you are using these technologies to introduce genetic variation that already exists in wild relatives," says Custers. "The question is whether or not that differs from traditional plant breeding." Custers therefore advocates a definition that excludes plants carrying genetic changes that are already present in nature.

But including such plants in the definition does not mean that they would be heavily regulated, notes Greg Jaffe, director of biotechnology at the Center for Science in the Public Interest, a consumer advocacy group in Washington DC. "The USDA is capturing them under the rubric, but it sounds like they're also going to exempt many of them from oversight," he says.

Some activists are unlikely to support the idea. Gurian-Sherman notes that gene-editing technology is still relatively new, can be applied in many ways and sometimes makes unintended genetic changes. "We feel very strongly that this technology still needs to be regulated as we learn more about it," he says. "Maybe at some point it wouldn't need to, but this is still a new technology."

FUNDING

Lab fights grant
rejection and wins

Scientist hired lawyer to challenge European Commission.

\section{BY EWEN CALLAWAY}

$\mathrm{F}$ Taced with a rejected grant application, scientists usually experience a range of emotions - shock, sadness, anger - before accepting the verdict and moving on. But when the European Commission rejected a $€ 5$-million (US\$5.7-million) grant application from computational scientist Peter Coveney, he hired a lawyer and challenged the decision.

The successful appeal, made public on 29 March, highlights an aspect of the research-funding process that scientists rarely act on and almost never succeed at.

"I've been told by colleagues that you don't challenge the commission on anything," says Coveney, of University College London (UCL). "But if your research is in jeopardy as a part of poor decisions, then people should be prepared to challenge them."

Coveney thinks that his rare victory should encourage more researchers to appeal against decisions made by funders. But funding-agency administrators warn that the chances of success are low - and that fruitless appeals can waste time and resources. "If you're going to play the odds here, your chance of getting funded is substantially higher if you submit a revised proposal than if you go down the route of submitting an appeal," says Michael Lauer, director of the Office of Extramural Research at the US National Institutes of Health (NIH), the world's largest biomedical funder.

Appeals are uncommon in both Europe and the United States. Between 2007 and 2013, the European Commission's Framework Programme 7 received more than 106,000 grant applications, but although around $80 \%$ were rejected, only 3,683 decisions were appealed. Of these, 101 were reevaluated and fewer than 10 succeeded in gaining funding. The US National Science Foundation, by comparison, received just 388 appeals between 2001 and 2014, 17 of which led to funding. Appeals at the NIH are similarly rare, says Lauer. Although the agency does not track them centrally, in eight years of overseeing cardiologyresearch grants, he saw just one successful challenge.

When the European Commission rejected the Coveney team's proposal to create a hub for applying computer modelling to biomedical and clinical data in May 2015, he was surprised. The 3-year project would involve 15 industrial and academic partners across Europe and use a consulting firm as project manager. Those elements fitted with a requirement for professional management, says Coveney, as outlined in the commission's funding call (part of a 7-year €78.6-billion programme called Horizon 2020). But he says that the reviews indicated that the team had brought in unnecessary partners by including the consulting firm, resulting in a poor score on that aspect.

\section{FOLLOW THE RULES}

Like some other funders, including the $\mathrm{NIH}$, the commission has a formal 'redress' process that allows spurned scientists to

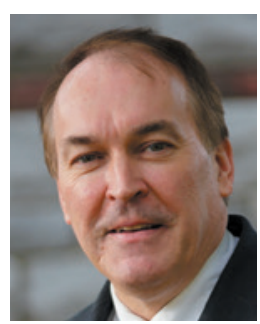

"Ifyour research is in jeopardy as a part of poor decisions, then people should be prepared to challenge them."

Peter Coveney ask for their grant applications to be re-reviewed. UCL advised Coveney that the odds of success were low. But he hired a law firm, Bindmans in London, to mount a challenge; his team incurred around $£ 10,000$ (US\$14,000) in legal fees. He learned that his grant would be reconsidered in October 2015, and later that it had scored well enough on this subsequent review to be funded in February this year. He got official word of its approval last month. A representative of the commission confirmed that the grant's initial evaluation report contained incorrect information, leading to a new evaluation.

"It is the only time I've challenged a grant decision so far in my life. I've seen a few dubious things happen in the past, but this one was so black and white," says Coveney. "It should send the message to people that they should think carefully and not just assume it's not worth it."

Not everyone agrees. "Lawyering up to 